\title{
Erratum to: Water Security Across the Gender Divide
}

Christiane Fröhlich, Giovanna Gioli, Roger Cremades, and Henri Myrttinen

\author{
Erratum to: \\ C. Fröhlich et al. (eds.), Water Security Across the Gender \\ Divide, Water Security in a New World, \\ https://doi.org/10.1007/978-3-319-64046-4
}

This book was inadvertently published with inconsistent information in the author group of chapters 4 and 11. This has now been amended throughout the book to Mauro van Aken (first author of the chapter 4), and Lynette de Silva (first author of the chapter 11) respectively.

\footnotetext{
The updated online version of this book can be found at https://doi.org/10.1007/978-3-319-64046-4_4 https://doi.org/10.1007/978-3-319-64046-4_11 https://doi.org/10.1007/978-3-319-64046-4
} 